\title{
New Social Risks, Korean Families, and Policy Challenges
}

Dr. Eunyoung CHOI

Department of Child Welfare

Chungbuk National University

South Korea

Email: eychoi66@chungbuk.ac.kr

Paper to be presented in the Panel

'New Social Risks and New Family - Changing Paradigm of Asian Way of Welfare?' The $4^{\text {th }}$ Annual East Asian Social Policy research network International Conference University of Tokyo, Tokyo, Japan

October 20 - 21, 2007

[ Draft, please do not quote. Comments welcomed. ] 


\section{New Social Risks, Korean Families, and Policy Challenges}

\section{Introduction}

Korean welfare state is facing diverse pressures and challenges more than ever. Prevalence of precarious jobs due to labor market numerical flexibility, polarization of job quality as well as opportunities of skill development and training, weakened family functions and increase of untraditional families, serious barriers in balancing paid work and family responsibilities, lowest fertility rate and most rapid ageing of population in OECD countries, and insecure or inadequate pension and uncoordinated services, etc..

These big challenges which indicate a new type of social risks have been opening a series of discussion on the care crisis, on re-building the family-state responsibility and re-shaping the gender relations, and on integrating labor market policy and social programs in Korea as well as other welfare countries.

The old social risks such as retirement, ill health, poverty, unemployment many families have confronted did not disappear and now are even intertwined with the so-called "new social risks", thereby Korean welfare state is facing complicated reform tasks in several policy fields.

This study attempts to elaborate the current situation and context of these policy challenges in Korea, and to zero in the diverse driving forces that formulate Korean welfare state reform in recent decade. This study will shed light on a better understanding on the critical risks Korean families confront and the characteristics of recent Korean welfare state restructuring in response to them. Among all the new social risks, work-life balance issues and low fertility, and labor market polarization and consequent income inequality are mainly discussed.

\section{Work-Family balance and low fertility}

The cause of the difficulty of women who work and bring up children at the same time can be discussed in two aspects: first, the level of socialization of child-rearing is low in Korea and women are more responsible for raising children in the family because of the unshared responsibilities between husband; and second, women postpone pregnancy and giving birth since they have lesser chances in having a stable job. It is a harsh reality that women's role of childbirth (reproduction) is a huge disadvantage in economic activities in Korea. The labor 
market participation rate of women in Korea belongs to the lowest group among the OECD countries. LMPR of women with tertiary education has been more seriously low (see Figure 2-1).

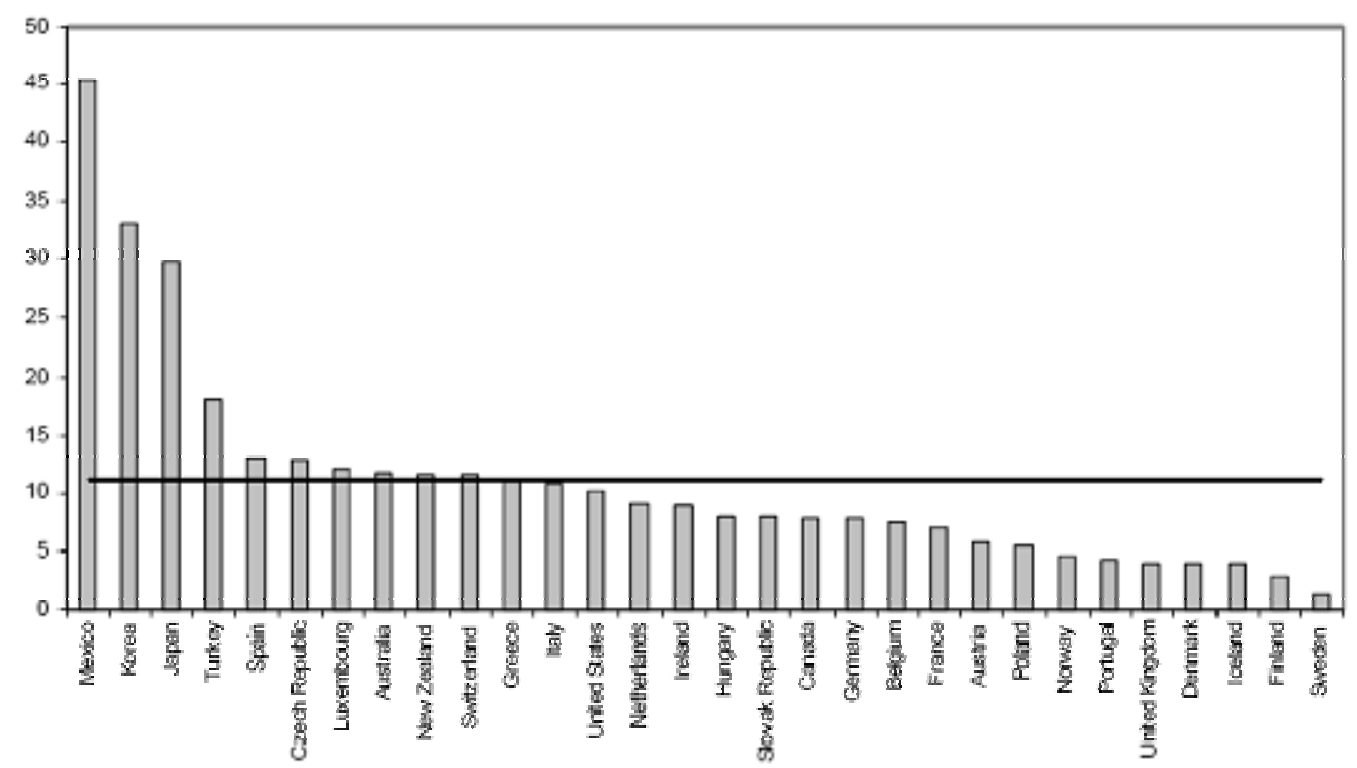

Note: Percentage point difference between the employmentpopulation ratios for men and women with tertiary education

Source: OECD (2004), Empioyment oulook.

[ Figure 2-1] Women's LMPR compared to Male Counterparts

What choice do married women workers who have kids make for work and child rearing? To answer this question, let's take a look at the results from Korean Women Link's survey in 2003. This research interviewed married men and women who both work and raise their children under 12 years old (Jang and Bu 2003). The two questions in the survey were asked "if they have considered discontinuing work due to pregnancy or childbirth" and "if they have practiced birthcontrol for working better at the workplace". The results are categorized into four types as seen in Table 2-1. Women's responses are presented too.

First of all, women who have considered discontinuing work and practiced birth control can be considered as those who had strong conflict between work and child rearing. This case accounted for almost $30 \%$ of the entire respondents. Those who did not consider discontinuing work but practiced birth control accounted for $17.8 \%$. Only $1 / 4$ of the entire married women workers live reconcilable lives, without experiencing both discontinuing work and birth control.

Table 2-1. Hidden Choice of Women who Work and Raise their Children: Ideal Types and responses 


\begin{tabular}{c|c|c|c}
\hline \multicolumn{2}{c}{} & \multicolumn{3}{|c}{ Considered Quitting Work } \\
\cline { 2 - 4 } Controlling the & \multirow{2}{*}{ YES } & YES & NO \\
Number of & & Conflict & Career-oriented \\
Children & \multirow{2}{*}{ NO } & Children-oriented & 17.8 \\
& & 27.6 & Stable \\
& & & 25.1 \\
\hline
\end{tabular}

Source: Jang and $\mathrm{Bu}(2003)$

According to a national survey on fertility, marriage, and family lives of 2005, women's employment status is different by life cycles: parenthood without children (group 1), parenthood with children of preschool age (group 2), and finally parenthood with school age children (group 3). In general, the major employment status of each group is wage labor. But the distribution has changed as the life cycle changes. As wage labors in group one hold $79.6 \%$, this ratio has decreased to $54.4 \%$ in group two and rather the ratio of self employed and non-wage labor have increased. In group three, the ratio of self employed and non-wage labor are a bit higher than in group two. Through the entire life cycle, the ratio of women working as employers is consistently low (see figure 2-2).

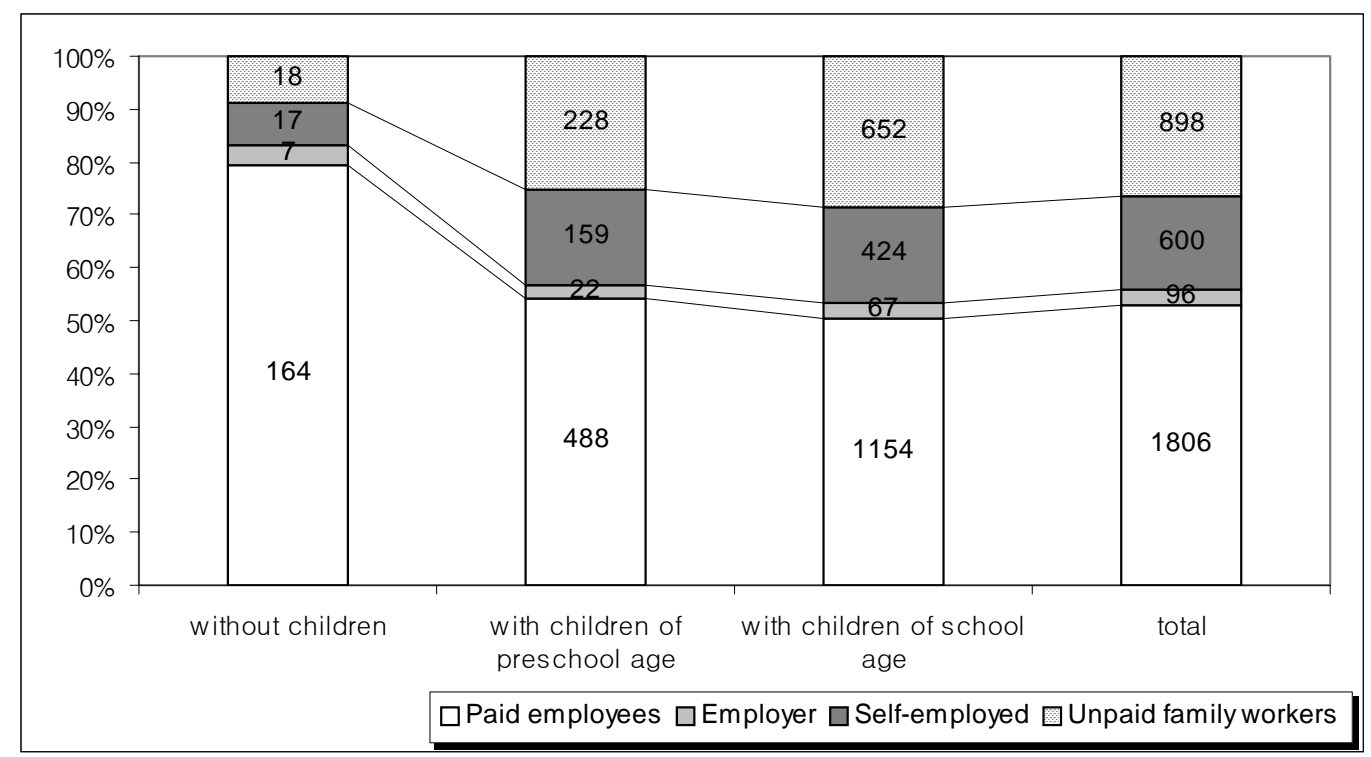

[ Figure 2-2] Women's Employment Status by life cycle

A comparative study (Chang, 2005) also shows that the higher the gender equality in employment, the higher the total birthrate. The significant meaning of this analysis is as follows: De-burden the family by improving child care service, instead of the government paying direct 
compensation for recognizing care value. It seems that the policy paradigm that pursues both deburdening of families from child care work and equality of gender in employment, with emphasis on women's right to work has been much superior than other paradigms in terms of total fertility rate. It is obvious that such a policy paradigm will be highly effective in encouraging women's participation in economic activities too.

The discussion on the relationship between the level of gender equality in the labor market and birthrate is still an assumption and not many studies have been preformed to prove their causal relationship in Korea. There, however, seems to be a definitely strong association between these two variables in OECD countries through the 90s.

One survey shows that, only $25 \%$ of the entire women respondents took up their maternity leave without worrying back to work, whereas $75 \%$ were worried about several issues. Among these women, many were uncertain if they could return to their previous work after the maternity leave ended, and worried about potential disadvantages in promotion and job placement. This result indicates that, in reality, maternity leave became a hindrance to the career development of women workers in the labor market, although maternity leave is a surely guaranteed right by law.

Korea recorded the lowest fertility rate of 1.08 in $2005^{2}$ and has been working on building up national policy measures to cope with this situation. Some scholars find the cause of low fertility rates in the value changes. In fact, many theories and discussions support this view: for example, one theory explains that as the post-industrial society sets in, where social solidarity is weakening, individuals' independence and responsibility are much more emphasized, and economic and social security lessens, people increasingly tend to have fewer children (McDonald, 2005). Another interpretation suggests that in a consumer-oriented society, childbearing and consumption are often thought as a trade-off (Longman, 2004).

Changes in values, of course, can remarkably reduce the ideal or wanted number of children compared to what it was in the past era and the theory indeed explains the phenomenon of the big decline of number of children compared to 1960-70's in Korea. It, however, does not fully explain why people often fail to have their expected number of children. In a search for possible answers to this question, this section reviews childcare and parental leave as important vehicles for women's work-family balance.

\footnotetext{
${ }^{2}$ It slightly rises into 1.13 in 2006. The causal explanations are under detailed scrutiny.
} 
The fact that child-care and parental leave reduce indirect (opportunity) costs incurred by childrearing suggests that they help prevent career interruptions and exit from the labor market for parents. In other words, they help balance work and family. Granted, ideally, the reconciliation of work and family should also involve changes in corporate practices and employment patterns and a diversity of family-friendly fringe benefits, but this is beyond the scope of this paper. Below, following section examines the relationship between having children and participating in economic activities and, negative effects of children on career. It then explores the current situation of child-care and parental leave services in Korea as support measures of childbearing.

Married couple's participation in economic activities depends on whether the reserved wage is higher or lower than the wage provided at the market. Interestingly, in this regard, are the research results that demonstrate while the labor supply of married men is mainly a function of wage and unearned income, the labor supply of married women is heavily influenced by the number of children and the children's ages too (Blau et al. 1998). That is, the time and cost required to raise children have tremendous impact on the labor supply of married women. It then can be inferred that in addition to financial support, the supply of child care facilities with high accessibility is closely tied to married women's labor supply decisions and survival(retention).

Concerning childcare policies, childcare centers, not only for children aged 3-6 but also for children under age 3, were especially emphasized. Keeping in mind that career interruptions mostly take place to mothers with younger children, this emphasis is quite understandable. At the same time, it was reported that in-kind childcare benefits do a better job than cash allowance. The experience of Norway, which started from 1998 to pay home care allowances to families with children under age 2, tells a strong story. Since the introduction of the cash policy in Norway, married women's participation in the labor market dropped by $7 \sim 8 \%$ in the short term and the decrease rate is expected to be as large as $16 \%$ in the long run (Kornstad and Thoresen 2002).

If it is the case, in order to pursue both employment and childbearing and not just childbearing only, it is concluded that more efforts should be made to expand childcare services rather than providing for parental leave payments. In fact, much research that has been delved into the relationship between children and women's economic activities in OECD countries pose several questions. Table 2-2 examines the quality of childcare policies in terms of availability and 
affordability and compares them based on three regimes of welfare state. It is found that having children had a very different degrees of negative impact between countries with weak social supports and those with strong supports. In all English-speaking countries, the presence of children is an obstacle to mothers' employment, and Norwegian women are in more disadvantages to getting a job due to a lack of comprehensive childcare services than women in other Nordic countries.

The results of these empirical studies clearly illustrate the negative impact of both the presence and the number of children on employment and the positive buffering effects of childcare and childrearing support policies on reducing/eliminating this negative impact. The causal relationship more or less runs along the lines of the theory that market participation increases when the reservation wage is lower and that market labor increases when time-intensive childcare is socially concerned and appropriately supported. In order to help level up married women's participation in the labor market, Korea needs to make a concerted effort to bring down the reservation wage by providing public childcare and support for childcare expenses as well as making the under-used maternity and parental leaves more substantial and effective.

Table 2-2. Relationship between the Social Provision of ECEC (Early Childhood Education and Care) and Maternal Employment

(H: High, I: Intermediate, L: Low)

\begin{tabular}{|c|c|c|c|c|}
\hline & \multicolumn{2}{|c|}{$\begin{array}{l}\text { Social distribution of ECEC } \\
\text { (Availability in supply/costs) }\end{array}$} & \multicolumn{2}{|c|}{ Penalty to maternal employment due to children* } \\
\hline & Aged 0-2 & Aged 3-5 & $\begin{array}{l}\text { Reduction in } \\
\text { maternal employment } \\
\text { (Children aged 0-2) }\end{array}$ & $\begin{array}{l}\text { Reduction in } \\
\text { maternal employment } \\
\text { (Children aged 3-5) }\end{array}$ \\
\hline \multicolumn{5}{|c|}{ Socialist democratic countries } \\
\hline Denmark & $\mathrm{H} / \mathrm{H}$ & $\mathrm{H} / \mathrm{H}$ & $0 \%$ & $0 \%$ \\
\hline Finland & $\mathrm{I} / \mathrm{H}$ & $\mathrm{I} / \mathrm{H}$ & $0 \%$ & $0 \%$ \\
\hline Norway & $\mathrm{I} / \mathrm{H}$ & $\mathrm{I} / \mathrm{H}$ & $-29 \%$ & $-27 \%$ \\
\hline Sweden & $\mathrm{H} / \mathrm{H}$ & $\mathrm{H} / \mathrm{H}$ & $0 \%$ & $0 \%$ \\
\hline \multicolumn{5}{|c|}{ Conservative countries } \\
\hline Belgium & $\mathrm{I} / \mathrm{H}$ & $\mathrm{H} / \mathrm{H}$ & $0 \%$ & $0 \%$ \\
\hline France & $\mathrm{I} / \mathrm{H}$ & $\mathrm{H} / \mathrm{H}$ & $0 \%$ & $0 \%$ \\
\hline Germany & $\mathrm{L} / \mathrm{L}$ & $\mathrm{I} / \mathrm{I}$ & $-25 \%$ & $-117 \%$ \\
\hline Italy & $\mathrm{L} / \mathrm{L}$ & $\mathrm{H} / \mathrm{H}$ & n.a. & n.a. \\
\hline Luxemburg & $\mathrm{L} / \mathrm{L}$ & $\mathrm{H} / \mathrm{H}$ & $0 \%$ & $0 \%$ \\
\hline Netherlands & $\mathrm{L} / \mathrm{L}$ & $\mathrm{H} / \mathrm{H}$ & $-25 \%$ & $-21 \%$ \\
\hline \multicolumn{5}{|c|}{ Liberalist countries } \\
\hline Australia & $\mathrm{L} / \mathrm{L}$ & $\mathrm{I} / \mathrm{I}$ & $-35 \%$ & $-15 \%$ \\
\hline Canada & $\mathrm{L} / \mathrm{L}$ & $\mathrm{I} / \mathrm{I}$ & $-15 \%$ & $-10 \%$ \\
\hline UK & $\mathrm{L} / \mathrm{L}$ & $\mathrm{I} / \mathrm{I}$ & $-45 \%$ & $-31 \%$ \\
\hline
\end{tabular}




\begin{tabular}{lllll}
\hline US & $\mathrm{L} / \mathrm{L}$ & $\mathrm{I} / \mathrm{I}$ & $-22 \%$ & $-15 \%$
\end{tabular}

Note: * The expected decrease of percentage points (penalty) in employment was calculated in consideration of many elements, such as marital status, number of children, age and educational background of mothers, and household income, of married women with young children.

Source: Meyers and Gornick (2003).

It was surveyed that the fill-up rates for childcare were $46.6 \%$ for infants and $85.4 \%$ for young children, with 72.3\% overall in 2004 (See table 2-3, and figure 2-3). The fill-up rate for infants of under the age of 1 is the lowest. The estimated mid-term additional demands based on the respondents who said they would send their babies to childcare centers within a year are tallied at 250,000 infants and 150,000 young children.

Table 2-3. Estimated Mid-term Additional Demand for Early Child Care and Education by Age

\begin{tabular}{|c|c|c|c|c|c|c|c|c|}
\hline \multirow[b]{2}{*}{ Classification } & \multicolumn{4}{|c|}{ Early Child Care } & \multicolumn{4}{|c|}{ Early Child Education } \\
\hline & $\begin{array}{c}\text { Use } \\
\text { rate (A) }\end{array}$ & $\begin{array}{l}\text { Additional } \\
\text { wished } \\
\text { use rate } \\
\text { (B) }\end{array}$ & $\begin{array}{l}\text { Demand } \\
\text { rate } \\
(\mathrm{C}=\mathrm{A}+\mathrm{B})\end{array}$ & $\begin{array}{c}\text { Fill-up } \\
\text { rate } \\
(\mathrm{A} / \mathrm{C} \times \\
100)\end{array}$ & $\begin{array}{l}\text { Use } \\
\text { rate } \\
\text { (D) }\end{array}$ & $\begin{array}{l}\text { Additional } \\
\text { wished } \\
\text { use rate } \\
\text { (E) }\end{array}$ & $\begin{array}{l}\text { Demand } \\
\text { rate } \\
(\mathrm{F}=\mathrm{D}+\mathrm{E})\end{array}$ & $\begin{array}{c}\text { Fill-up } \\
\text { rate } \\
(\mathrm{D} / \mathrm{F} \times \\
100)\end{array}$ \\
\hline $\begin{array}{l}\text { Infant } \\
\text { Aged } 0 \\
\text { Aged } 1 \\
\text { Aged } 2 \\
\text { Subtotal } \\
\end{array}$ & $\begin{array}{c}2.3 \\
12.4 \\
28.5 \\
15.1\end{array}$ & $\begin{array}{c}7.8 \\
13.0 \\
29.3 \\
(17.3) \\
\end{array}$ & $\begin{array}{l}10.1 \\
25.4 \\
57.7 \\
32.4 \\
\end{array}$ & $\begin{array}{l}29.8 \\
48.8 \\
49.4 \\
46.6 \\
\end{array}$ & & & & \\
\hline $\begin{array}{l}\text { Young } \\
\text { Children } \\
\text { Aged } 3 \\
\text { Aged } 4 \\
\text { Aged } 5 \\
\text { Subtotal }\end{array}$ & $\begin{array}{l}45.7 \\
42.9 \\
28.9 \\
38.5\end{array}$ & $\begin{array}{c}19.1 \\
5.8 \\
0.6 \\
(6.6)\end{array}$ & $\begin{array}{l}64.8 \\
48.7 \\
29.5 \\
45.1 \\
\end{array}$ & $\begin{array}{l}70.5 \\
88.1 \\
98.0 \\
85.4\end{array}$ & $\begin{array}{l}13.5 \\
25.7 \\
50.1 \\
31.1\end{array}$ & $\begin{array}{l}23.2 \\
29.3 \\
10.5 \\
18.9\end{array}$ & $\begin{array}{l}36.7 \\
55.0 \\
60.6 \\
50.0\end{array}$ & $\begin{array}{l}36.8 \\
46.7 \\
82.7 \\
62.2\end{array}$ \\
\hline Total & 28.5 & $(10.9)$ & 39.4 & 72.3 & 31.1 & 18.9 & 50.0 & 62.2 \\
\hline
\end{tabular}

Note: The population used in the table is the one for Special Population Prospects of 2004, National Statistical Office, 2005.

Source: National Survey of Childcare Use and Demand, 2004(latest survey). 

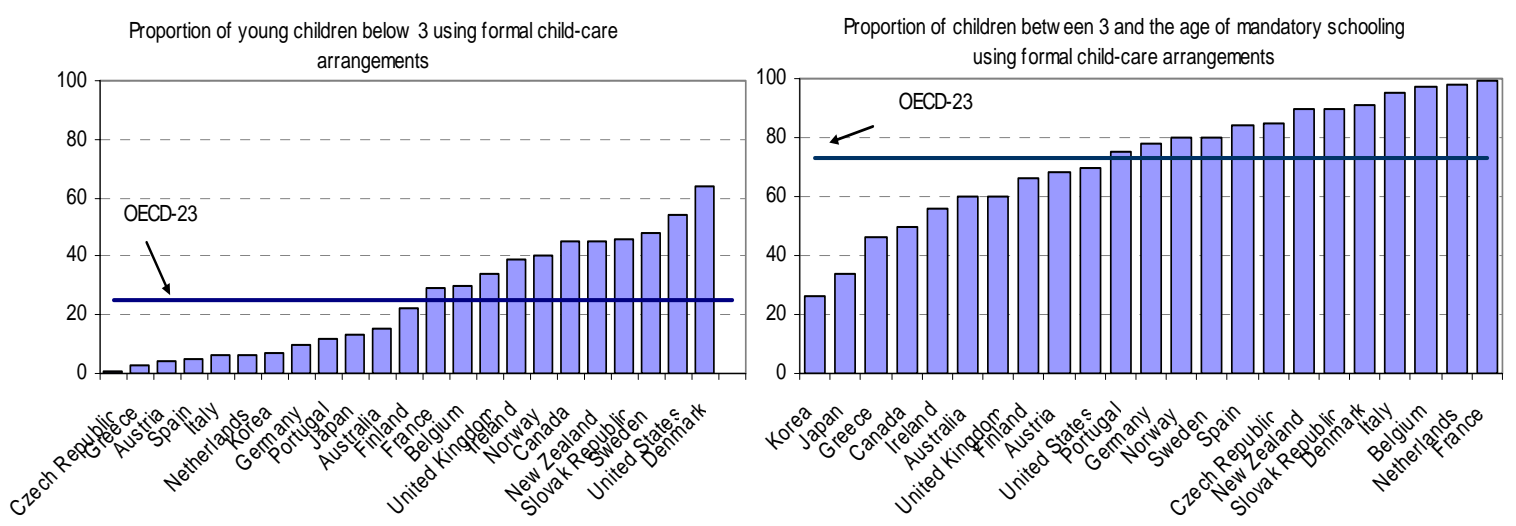

[ Figure 2-3 ] Share of children of different ages attending formal childcare arrangement Source: d'Addio and d'Ercole (2005).

Particular attention needs to be paid to the great difference between the use rate of childcare support facilities and mothers' employment rates by age of children. Mothers with young children have markedly low employment rates (see table 2-4).

Table 2-4. Use of Child-care Support Facilities

\begin{tabular}{|c|c|c|c|c|c|}
\hline Classification & $\begin{array}{c}\text { Number of } \\
\text { Population '04 }\end{array}$ & $\begin{array}{c}\text { Childcare } \\
\text { Facilities } \\
\text { (June 2004) }\end{array}$ & $\begin{array}{l}\text { Kindergarten } \\
\text { (April 2004) }\end{array}$ & Subtotal & $\begin{array}{c}\text { Mothers' } \\
\text { Employment } \\
\text { Rate (2004) }\end{array}$ \\
\hline Aged 0 & 481,264 & $15,567(3.2)$ & & $15,567(3.2)$ & 20.2 \\
\hline Aged 1 & 480,140 & 64,219(13.3) - & & 64,219(13.3) & 24.5 \\
\hline Aged 2 & 514,835 & $159,443(31.0)-$ & & $159,443(31.0)$ & 35.9 \\
\hline Subtotal (Aged 0-2) & $1,476,239$ & $239,229(16.2)-$ & & $239,229(16.2)$ & 26.8 \\
\hline Aged 3 & 595,786 & $225,229(40.4)$ & $76,829(12.9)$ & $302,058(53.3)$ & 43.4 \\
\hline Aged 4 & 614,730 & $214,110(34.8)$ & $168,613(27.4)$ & $382,723(62.1)$ & 40.1 \\
\hline Aged 5 & 621,373 & $182,562(29.3)$ & $296,271(47.7)$ & $478,833(77.0)$ & 44.9 \\
\hline Subtotal (Aged 3-5) & $1,831,889$ & 621,901(34.0) & 541,713(29.6) & $1,163,614(63.6)$ & 42.6 \\
\hline Aged 6 & 638,889 & \multirow{4}{*}{\multicolumn{3}{|c|}{$\begin{array}{l}\text { Using classrooms at elementary schools after school: } 7 \% \\
\text { Using private institutes, including private academy: } 71.6 \%\end{array}$}} & 44.8 \\
\hline Aged 7 & 668,287 & & & & 51.2 \\
\hline Aged 8 & 688,387 & & & & 47.1 \\
\hline Subtotal (Aged 6-8) & $1,995,563$ & & & & 47.6 \\
\hline
\end{tabular}

Source: Special Population Prospects, National Statistical Office, 2005; Kindergarten Statistics, Ministry of Education and Human Resources Development, June 2004; Childcare Statistics, Ministry of Gender Equality, June 2004. 
In conclusion, there has been a vicious circle; the lowest fertility and low LMPR of women are reinforcing each other under the condition of less socialization of child-rearing and labor market discrimination (see figure 2-4).

[Figure 2-4] Relationship of Low Fertility and the Low Labor Market Participation Rate

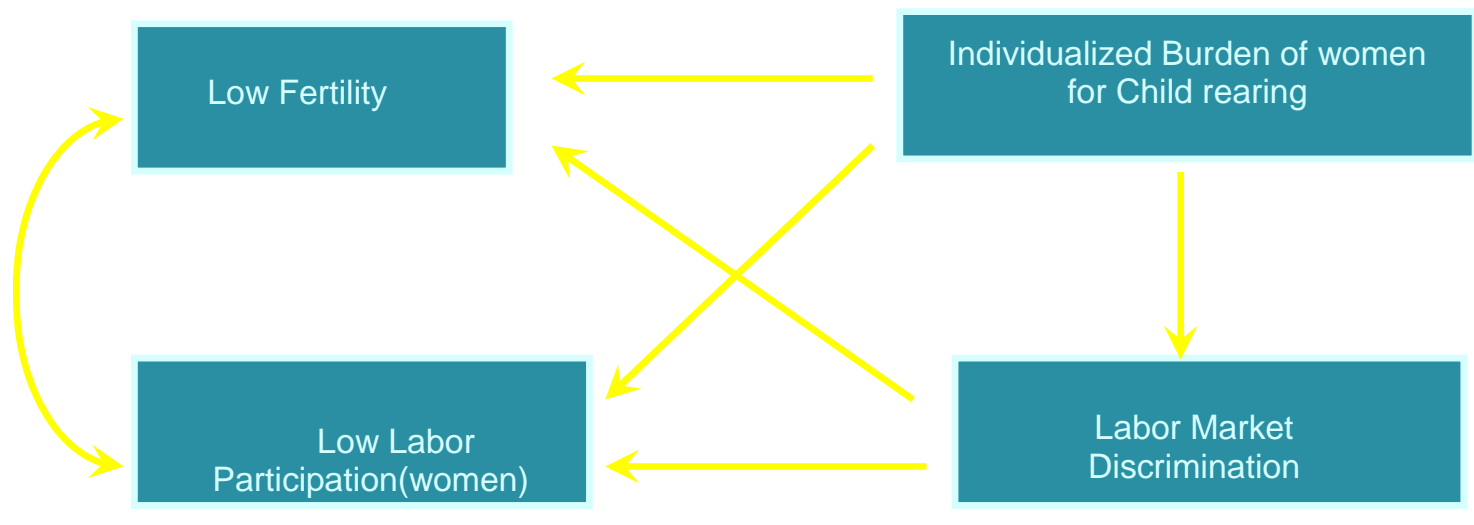

Source: Jang (2005)

The most important way to have a positive correlation on childbirth rates and women's employment rate is to shape work-family life reconciable. This is also the lesson that we can learn from OECD countries through their experience of recovering fertility rates by creating familyand women-friendly employment and service environments. More specifically, the following policy efforts are needed:

o Enhance accessibility to childcare facilities

o Meet consumers' demands by having flexible operation and diverse programs

o Enhance the quality of services at childcare facilities

o Make flexible use of maternity and parental leaves in both time and duration

o Increase the income replacement rate during parental leave periods

o Separate allocations of parental leave to fathers and mothers

The more society stresses the traditional functions of the family, adheres to the traditional gender division of labor and unilaterally sticks to policy paradigm for economic growth and labor productivity, the more women and parents experience gaps between working in the labor market and childrearing in their daily lives. In the broader picture, policies should be effectively 
designed for changing current structure of the responsibility between the market, the family, and the state, and between women and men, a deep structure that Korean society has long been kept.

In this regard, we are called for to ponder the type of welfare regime we should pursue. For example, the Nordic model, led by Denmark and Sweden, has as the major policy goal of full employment, women's participation in the labor market, and gender equality. France has a century long history of encouraging childbirths and supporting the family. On the other hand, Germany still adheres to the traditional role of mothers and minimal intervention of the family by the state. The Anglo-American model dictates non-intervention, or limited intervention for low-income families only. Even when a consensus can be built on the welfare regime that we should take, we still have the comprehensive and challenging task of shaping an effective and integrated policy paradigm through reviewing and coordinating with other institutions and policies.

\section{Labor market insecurity and income inequality}

Labor market is radically changing by the twin forces of globalization ${ }^{3}$ and technological advances in all over the world, so it is often said that current labor market can no longer deliver the employment and social securities of the past. Then the degree of insecurity of Korean labor market can be defended as an inevitable one? It is also often suggested that new securities need to be developed for employees' protection in post-industrial society. Is Korean government well managing this task and has made some progress? This section attempts to answer to these two important questions.

One of the most often-used buzzword in Korea is (bi-)polarization since the 1997 financial crisis. Several aspects of polarization have been witnessed in terms of income, labor market, industry, education etc. It would be safe to say that the most prominent ones are income disparity and labor market polarization in terms of both wage and job security. I argue the latter is a more severe problem since the latter brought about and aggravated the former. Forster and Pearson (2002) also pointed out that one of the main driving forces of income inequality in OECD was employment polarization, leading to an increase in working poor shares of households.

\footnotetext{
3 The Korean government (with Kim Youngsam president) actively started to pursue globalization strategy from the mid-1990s.
} 
Major concerns in Korea have been raised on the size of insecure irregular workers as well as erosion of permanent employment. In fact, temporary employment and daily jobs has tended to replace secure regular jobs, not create new jobs. In this context, it is argued that Korea is doing worse than any where else because the loss of regular jobs in favor of more precarious, atypical forms of employment has been more severe and prominent (Schmidt 2007). According to OECD(2002), non-regular employment accounted for 11 percent of salaried employment in the OECD as a whole in 1985, and for 14 percent in 2000. Compare this with Korea, where over the past four years 1997 through 2000, the share of non-regular employment has gone from $45.6 \%$ to $52.1 \%$ as economy lost over 88 thousand regular jobs while creating over 86 thousand nonregular jobs (see table 3-1). Therefore it would fair to say that polarization of labor market or labor market dualism goes without producing new jobs, insecure jobs simply replace secure ones.

Table 3-1. Number changes of types of employees (1996-2001)

Unit: thousand person

\begin{tabular}{|l|l|l|l|l|l|l|}
\hline & 1996 & 1997 & 1998 & 1999 & 2000 & 2001 \\
\hline regular & 7499 & 7282 & 6534 & 6135 & 6395 & 6714 \\
\hline temp & 3907 & 4236 & 4042 & 4255 & 4608 & 4726 \\
\hline daily & 1794 & 1868 & 1720 & 2274 & 2357 & 2218 \\
\hline
\end{tabular}

Source: NSO, Korea

The average job tenure of Korea in 2002 was only 5.6 years, compared to 12.2 years of Japan, 8.4 years of Denmark and so on. According to the ILO's comparative study on employment stability and flexibility (Auer and Cazes 2003), it is also possible for firms to suffer profit loss from low tenure and high mobility of labor force because high turnover and frequent change of jobs indicate that human capital and organizational asset may be quickly eroded. Therefore, certain levels of stable employment relationships are needed both for employers and employees in the long-term. Otherwise, the decline in investment and demise of the long-term growth potential are unavoidable, which already emerge in Korea.

Job security, of course, depends not only on tenure and also on many factors such as overall unemployment, the size and frequency of lay-offs, and the consequences of lay-offs in terms of income security and job-finding rates (OECD 1997). It is the government's role to secure employees by providing optimal degree of employment protection as a social risk-management and a coordination of market forces, dealing with all the factors mentioned earlier. 
The most serious problem irregular workers suffer has been a low wage. An average wage of irregular workers was almost 50 70 percent of that of regular workers in 2004. In addition, they often left out of several fringe benefits from companies.

Badly enough, non-regular employees are also substantially less covered by work-based social insurances. 47 percent of non-regular employees are covered by the National Pension, 49 percent are covered by health insurance, and 45 percent are covered by unemployment insurance. The financial crisis in 1997 has increased insecurity at the labor market mainly for non-regular workers, and existing social protection system could not adequately deal with their vulnerabilities.

Table 3-2 shows changes in the income shares of the richest 20 percent of households and the other 80 percent, pre- and post-crisis. It represents gains of richest and reduction of the income share of the non-rich, which results in income polarization. Obviously, Gini- coefficient rose after the financial crisis.

Table 3-2. Financial crisis and changes in income shares

\begin{tabular}{|c|c|c|c|}
\hline \multicolumn{2}{|c|}{ Pre-crisis } & \multicolumn{2}{|c|}{ Post-crisis } \\
\hline $\begin{array}{l}\text { Income share of } \\
\text { bottom } 80 \%\end{array}$ & $\begin{array}{l}\text { Income share of top } \\
20 \%\end{array}$ & $\begin{array}{l}\text { Income share of } \\
\text { bottom } 80 \%\end{array}$ & $\begin{array}{l}\text { Income share of top } \\
20 \%\end{array}$ \\
\hline 61.2 & 38.8 & 58.3 & 41.7 \\
\hline
\end{tabular}

Source: abstracted from Schmidt (2007) p.24

Table 3-3. Simplified relations between EPL(Employment Protection Legislation) and social protection.

\begin{tabular}{|l|c|c|}
\hline & High level of social protection & Low Level of social protection \\
\hline High level of EPL & France & Japan \\
\hline Low level of EPL & Denmark & United States \\
\hline
\end{tabular}

Source: Auer and Cazes (2003) p.12

Table 3-3 shows typical cases of schematic relationship between employment protection and social protection. Denmark and the United States are countries with comparatively low tenure (although it is much higher in Denmark than in the United States) and high mobility, but have 
quite different labor market institutions. The United States combines low employment protection legislation with low social protection, whereas Denmark trades off low statutory employment protection against high social protection. France is a case in which those having the most secure employment are also those best protected once they lose their jobs. Japan is an excellent example of a country with high employment protection, although more in practice and custom than on a purely legislative bases, but low social protection for outsiders.

As we briefly compare those types with Korea, there are a combination of several negative characteristics; strong division between insiders and outsiders with no high employment protection or long tenure shown in Japan. The trade-off between relatively weak employment protection regulation and relatively generous social protection is found in Denmark. Danish system, therefore, creates a relatively small percentage of outsiders. What Korean workers are gaining in the name of labor market flexibility then? There is highly protected secure employment only for insiders in Korean labor market alongside with overall low level of social protection. A relative rigidity of insiders' labor market is weakening the Korean economy's capability for job creation in turn. What we are really trading off? What we are gaining and losing?

In a consequence of labor market dualism, the proportion of the working poor measured by the ratio of household income less than 50 percent of the median household income continuously increased from 8.38 percent in 1994 to 11.86 percent in 2005. If OECD measure (60\% criterion) applied, the poverty ratio increases 18.40 percent in 2005. More fundamentally, job insecurity and wage erosion has weakened domestic consumers' purchasing power in the long run (Yoon and Lee 2004).

It is more and more evident that the new social protection should be increasingly decoupled from employment since long-term and secure labor market attachment and life-long employeremployee relationships do not exist any more. The growing numbers of working-age people are unable to get adequate protection from employment relationships, so they need security on grounds other than work-record and employment, such as basic guarantee founded on citizenship.

\section{Participatory Government's Policies and Comments}

What have the participatory government's strategically pursue? 


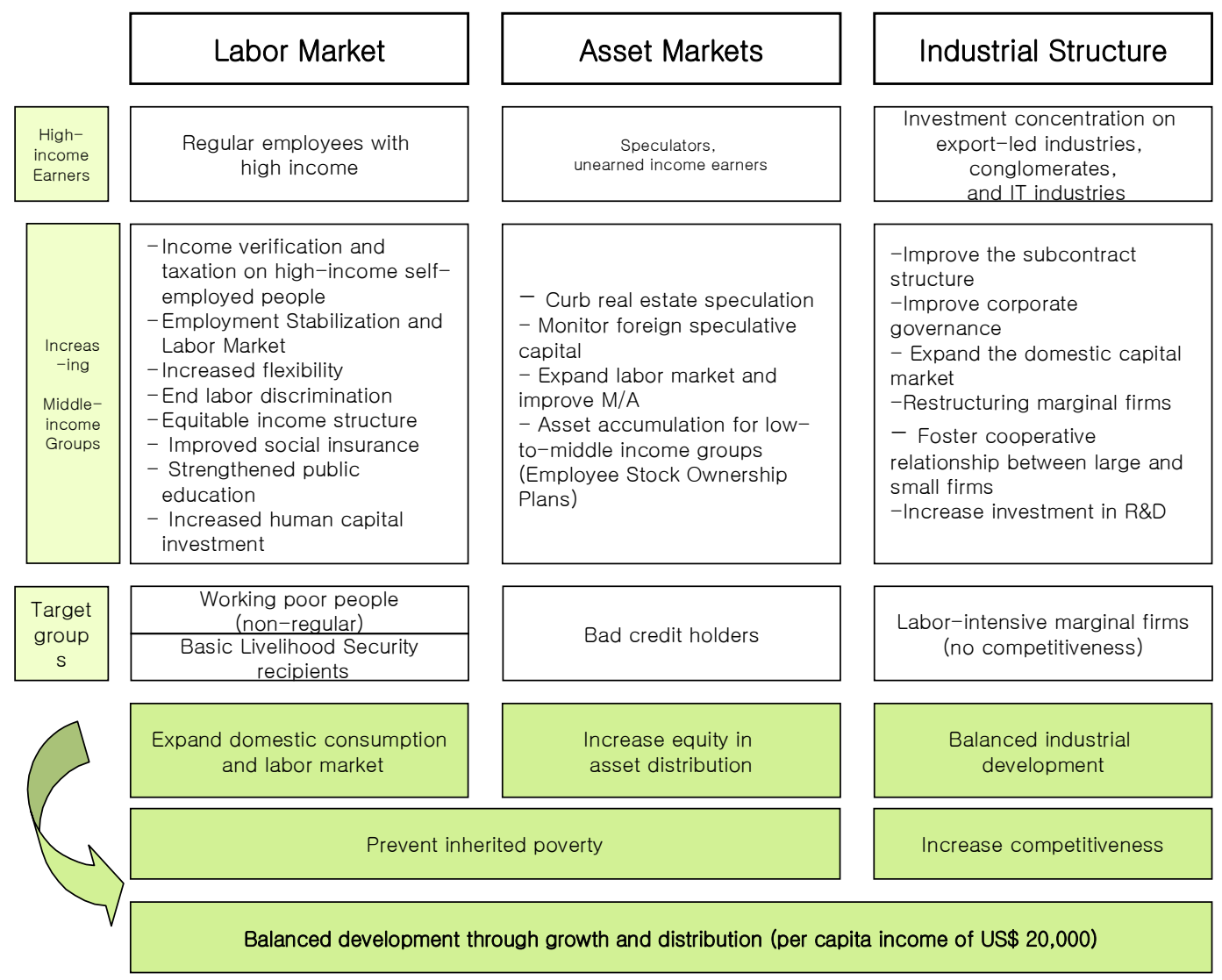

[ Figure 4-1 ] Participatory Government's Policies for Social Solidarity (2004) Source: Lee (2005) p. 114

Figure 4-1 describes several targeted policies in response to the newly emerging social risks. They are still working, and progress has been so slow.

What Korean government carried out recently?

Beginning July of 2007, a new legislation on the protection of fixed-term employees was in effect. It reinforces employers to re-post fixed-term employees into regular workers with stable employment relationships, right after 2-year contract. Employees were strongly against this law's enactment since this measure can be working as a tool for massive lay-offs only after two year employment. On the contrary, employers are demanding a permission of even more extensive use of externalized and outsourced workforce. Last 100 days, some companies re-allocate lots of temps into regular workers under the condition of a wage-freeze (ex: Woori Bank), at the same time, though, many fixed-term worker are laid off and more externalized too (ex: E-land Co.). 
We do not know yet which way is more up in the near future.

In August in 2007, amended National Pension law has been passed in the parliament. This new law lowers the replacement rate of pension benefits for the sake of financial sustainability. Though, this change may raise the number of vulnerable old and near-poverty line poors in the near future. In the long process of debate and discussion of the preparation of this change, citizens lost their confidence in the role of the state as a guard against vulgar market forces and as a facilitator of basic standard of living.

Capitalism has different faces. This is why capitalist states and economies are varied institutionally. Under the coordinated market economies, economic relations are coordinated mostly through non-market form of organizational structures. Wages are negotiated in a coordinated fashion at a sector level and not restricted to individual companies. The likelihood of long-term employment is greater. The educational system links up company-specific qualifications with industry-level qualifications (Hall and Soskice 2001). The uncoordinated market economies reveal a critical deficit: The companies concentrate merely on generating shortterm profits, and enough attention is not paid to the long-term impacts. Only the strategic practices and institutions can well manage the inherent contradictions between capital, labor, and state, and can achieve good balance.

What we need is, therefore, proper regulation of market, at least regulation of labor market not entire deregulation. From the comparative studies, it can be concluded that the labor market flexibility in Korea is much higher than any other countries, almost close to United States. Usually individual firm pursue the short-term profit and recently do not invest OJT or other forms of training/education for their employees. To make up for this weakness, public training system should be more stepped up and taking charge of human capital building for disadvantaged workers.

Overall, Korean welfare state lags way behind compared to the European welfare states. Political democratization was the hot issue during the last two decades, and overcoming the financial crisis was the top priority during the last ten years. Meanwhile, public interests and policy agendas on welfare have been put in the back burner. In Korea, the old social risks do not disappear nor are not diluted, and new social risks give more pressures the state to do more for solving the problems. On the contrary, the existence of huge number of uninsured and uncovered people under the current social insurances and public assistance program, has been emphasized 
as a critical drawback of Korean welfare state.

Some comfort can be drawn out of explicit policy directions of Roh's government which often called "pro-welfare". It is, however, also true that although the participatory government has widely opened debates on social welfare and agenda-building on the virtuous relationships between welfare and economic growth, the fruits have mostly not been sweet.

One of the sources of this struggle would be the fact that the old social risks are currently overlapped with new social risks, and massively yield too many problems for the state to handle at the same time. Many problems coming out of the labor market dualism and increasing income disparity cannot be fixing through social welfare system only, which is the second distributional mechanism. A solution needs to be delved out from changes in labor market system itself.

And the other source would be the limited financial resources under the current tax system. Are there any short-cuts for handling and solving the old and new social risks all together? I am afraid the answer is "no" considering the immature welfare system of Korea, conservativecorporatist social insurance schemes ${ }^{4}$ and huge proportions of uninsured people, labor market dualism, lack of infra structure of social services ${ }^{5}$, and relatively low level of expenditure. This diagnosis leads us to recognition of few choices; broadening tax bases and building up national consensus, which the participatory government has yet failed to achieve. The former is related to financial barrier (prospect), and the latter is related to political barrier (prospect). In 1997 before the financial crisis broke out, the social welfare expenditure as GDP percentage was only $4.3 \%$. It increased up to $6.1 \%$ in 2005 . However, it is still way low compared to other OECD countries. It should be raised. Market plays a role, but so do taxes and the government.

Besides the two dimensions of new social risks in Korea I have already mentioned, there have been several other changes which are and will be influencing overall well-being of Korean families and citizens: hand-over of many programs from central to local governments where tax revenues are unevenly distributed 6 , active pursuit of commercialization of social service

\footnotetext{
4 This maintains original social stratifications based on market status, and strengthened stratified outcomes in coverage, benefit level, and overall social protection.

${ }^{5}$ As of 2003, public expenditure on social services is only $14.7 \%$, compared to $15.4 \%$ of basic income guarantee, and $69.9 \%$ of four social insurances.

${ }^{6}$ This has been caused deepened inequality in welfare provision and unstableness of program implementation which often determined by the head of local government.
} 
provisions, income tax cut bill proposed on the $2^{\text {nd }}$ of October ${ }^{7}$. Furthermore, it seems that the right-wing coalition becomes stronger than ever compared to that of the so-called "progressives" in Korea.

The notion of "getting back to the traditional family and supporting the family's own strength and resilience" also exists in Korea. In actual, there have been serious conflicts between conservatives and progressives with regard to the roles and the functions of the family, family's diversity, and responsibility between the family and the state. In a more seriousness, there is even anti-(state) welfare attitude in conservative elite, come politicians and policy makers, growthoriented scholars, and undoubtedly conservative media. Though it can be safely claimed that in a policy-making stage, the underlying tone of current government's welfare policies are not based upon the old nostalgia on traditional family, and family-oriented welfare provision which one of the characteristics of East Asian welfare regime many scholars have been pointed out. The overburdened family is now starting to share their care responsibility with state and the third sector (NPOs), I argue.

In essence, globalization gives corporations a great deal of leverage and bargaining power over their workers. Together with conservative social insurance scheme, this naturally defends the interests of capital and business against labor and trade unions. In addition to that, Kim Daejung's government adopted and implemented neo-liberal finance mechanism and marketoriented labor market policies when we honestly look back. This inevitably impacts different segments of society in a very different manner. The new social relations between capital, labor, and the state were formulated one-sidedly in favor of capital (or business), so it failed to build balanced relations. Furthermore, it seems that Roh's government could not row the boat in the other direction nor overcame the legacies. Current government has not well managed the business sector's strategies for short-term profit maximization. It has not changed the unbalanced power between business and workers either.

\section{Conclusion}

\footnotetext{
${ }^{7}$ Considering the existing relatively low level of tax, and proposed several welfare visions of current government, this double-binding message could mislead and be misinterpreted by the people, and could ruin the possibility of comprehensive welfare.
} 

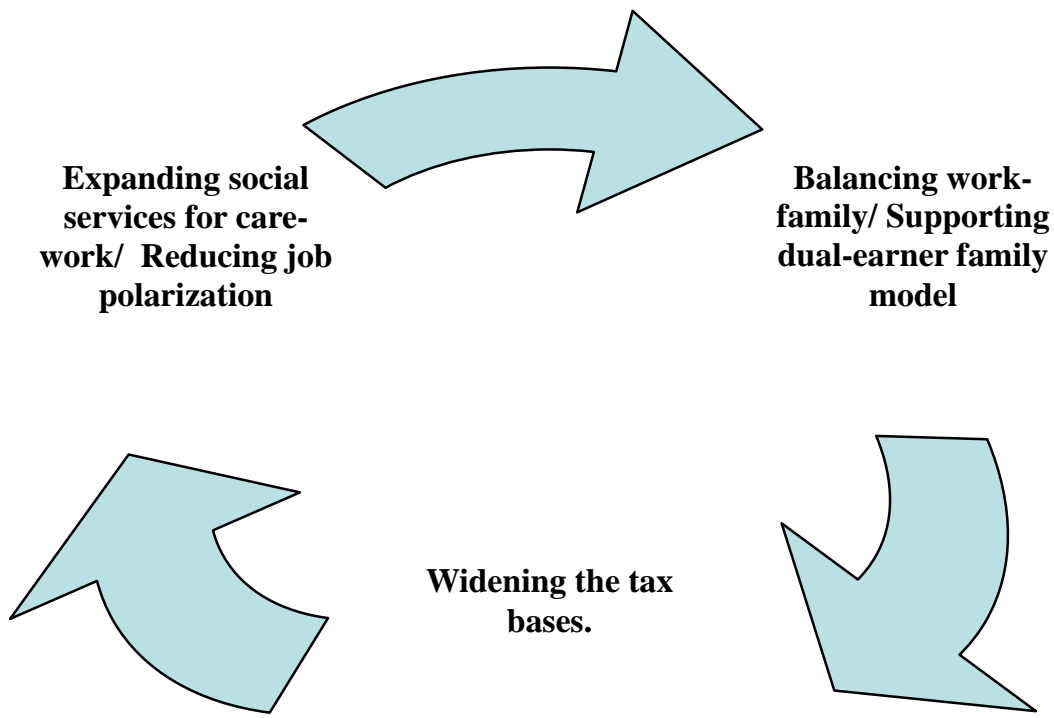

Widening the tax bases.

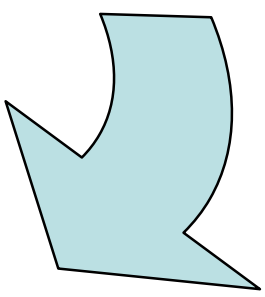

[ Figure 5-1 ] A virtuous cycle of new orientations of welfare policy

Figure 5-1 portrays a virtuous cycle of diverse welfare components for comprehensive, universal welfare. First, the government should expand social services which are based on needs. Essentially, social services can contribute to social integration overall and even have strong potential of job creation in Korean society. As mentioned earlier, special efforts to reduce job polarization are also needed. These are the fundamentals for balancing work and family of male and female workforce, and are best suited for higher employment rate and facilitating dualearner family model, which helps expansion of tax bases. Tax bases will be more widened when the tax evasion is effectively prevented and transparency is improved in tax administration. All of these in general, strengthen and support one another.

Are we going to catch up advanced full-fledged welfare state with coordinated market mechanism and gender equality, or will stuck in the residual welfare path with uncoordinated market and familialism? Some would simply argue that Roh's government tried numerous attempts over its capacity. Maybe just more time is needed to implement all the policies the participatory government has designed and proposed. Could we manage growing challenges, and finally get to a comprehensive, social service-oriented, and universal welfare state? Without concrete outcomes, vision itself and mind-comforting catch-phrases cannot solve the accumulated social risks. This coming Presidential election in December holds one of the keys to the answer in this complexity and to our future direction of welfarism. 


\section{Reference}

Auer, Peter and Sandrine Cazes (2003) Employment Stability in an Age of Flexibility: Evidence from industrialized countries, ILO: Geneva.

Blau, Francine et al. (1998) The Economics of Women, Men, and Work, Prentice Hall.

Bonoli, Giuliano. (2005) “The Politics of the New Social Policies: providing coverage against new social risks in mature welfare states", Policy and Politics, 33(3).

Choi, Eunyoung (2005) "Child-care and Parental Leave as Countermeasures against Low Fertility Rates", in Choi, Eunyoung et al. Low Fertility in Korea: Analysis on Socioeconomic Factors, Korea Institute for Health and Social Affairs, pp. 115-148.

d'Addio and d'Ercole (2005) Trends and Determinants of Fertility Rates: The Role of Policies, OECD.

Forster, Michael and Mark Pearson (2002) Income Distribution and Poverty in the OECD area, OECD Economic Studies, No. 34.

Hall, Peter A. and David Soskice (2001) Varieties of Capitalism: The institutional Foundations of Comparative Advantage. Oxford University Press.

Jang, Ji Yeon and Bu Ga Cheong (2003) "Hidden choice: Work and child rearing of married women workers," Research on Women, Vol. 65, Korean Women's Development Institute, 2003 (in Korean).

Jang, , Ji Yeon (2005) “Equality of Employment and Low Fertility", in Choi, Eunyoung et al. Low Fertility in Korea: Analysis on Socio-economic Factors, Korea Institute for Health and Social Affairs, pp. 281-320.

Kim, Jaejin and Park Neunghoo(2005) Evaluation of the Validity of the Korean Model of EITC, Korea Institute for Public Finance and Korean Institute for Health and Social Affairs, Policy Discussion Paper (in Korean).

Lee, Joung Woo (2005) “Redistribution with Growth: Redressing the Growthism of Four Decades" paper presented at International Symposium on Social Spending and Economic in OECD Countries, Nov. 22, 2007. pp. 105-130.

Longman, Philip (2004) The Empty Cradle, New America Books.

McDonald, Peter (2005) "Very Low Fertility: Its Causes and Remedies" paper presented at International Workshop on Low Fertility and Population Policies, KIHASA.

Meyers, Marcia K. and Janet Gornick (2003) "Public or Private Responsibility? Early Childhood Education and Care, Inequality, and the Welfare States", Journal of Comparative Family Studies, pp.379-411

OECD (1997) Employment Outlook, OECD: Paris.

OECD (2002) Employment Outlook, OECD: Paris.

OECD (2004) Employment Outlook, OECD: Paris.

Schmidt, Johannes D. (2007) "Globalizing Social Welfare and Labor Markets in East and Southeast Asia" paper presented at Diversity and Dynamics of Globalization, international conference organized by Korean Sociological Association. Sep. 13-14, 2007. pp. 3-42.

Yoon, Woojin and Lee Wonbok (2004) "' Stagnant Consumption and Its Causes", Monthly KIET Industrial Economics No. 71, August 2004. pp. 3-11, Korea Institute for Industrial Economics and Trade (in Korean). 